\title{
KREPŠINİ ŽAIDŽIANČIŲ STUDENTŲ SPORTINĖS VEIKLOS MOTYVACIJA
}

\author{
Romualdas Malinauskas \\ Lietuvos kūno kultūros akademija, Kaunas, Lietuva
}

\begin{abstract}
Romualdas Malinauskas. Profesorius socialinių mokslų daktaras. Lietuvos kūno kultūros akademijos Sporto pedagogikos ir psichologijos katedros vedėjas. Mokslinių tyrimų kryptis — sporto pedagogų ir sportininkų socialinio psichologinio rengimo ypatumai.
\end{abstract}

\section{SANTRAUKA}

Straipsnyje keliamas probleminis klausimas: kokie sportinès veiklos motyvai būdingi abieju lyčiu atstovams, kokie būdingesni merginoms ar vaikinams, kokie vidiniai ir išoriniai motyvai skatina jaunuolius isitraukti $i$ šia veikla. Tikrinama hipotezè, ar krepšinį žaidžiančiu studentu vaikinu sportinès veiklos motyvacija yra stipresne. Tyrimo tikslas - atskleisti krepšini žaidžiančiu studentu (merginu ir vaikinu) sportinès veiklos motyvacijos ypatumus. Tyrimo uždaviniai: 1) nustatyti krepšin̨žaidžiančiu (merginu ir vaikinu) sportinès veiklos vidinę motyvacija; 2) ištirti krepšini žaidžiančiu (merginu ir vaikinu) sportinès veiklos išorinę motyvacija.

Tyrimo metu pasitelktas modifikuotas $R$. Malinausko klausimynas sportinés veiklos motyvacijai tirti. Tiriamiesiems buvo pateiktas dešimties motyvu sqrašas vidinei motyvacijai vertinti ir šešiu motyvu sarašas išorinei motyvacijai tirti. Skirtumo patikimumas tarp krepšini žaidžiančiu vaikinu ir merginu buvo vertinamas pasitelkus procentini Studento t kriteriju. Tiriamaji kontingenta sudaré 95 krepšini žaidžiantys studentai (41 mergina ir 54 vaikinai), kuriu amžius - nuo 18 iki 24 metu. Tiriamieji atrinkti tikimybinès (dvipakopés mechaninès) atrankos büdu, atsitiktinai atrinktos aukštosios mokyklos ir atliktas ištisinis komandu, kuriose žaidžia studentai ir studentès, tyrimas. Buvo tiriami Lietuvos kūno kultūros akademijos (LKKA), Kauno medicinos universiteto (KMU) ir Vytauto Didžiojo universiteto (VDU) krepšin̨ žaidžiantys studentai - vaikinai ir merginos.

Ivertinus krepšin̨̨ žaidžiančiu studentu ir studenčiu vidinès sportinès veiklos motyvacijos ypatumus paaiškejo, kad vaikinams būdingesni $(p<0,05)$ nei merginoms šie motyvai: vidinio pasididžiavimo jausmas, noras patirti sèkmę, noras siekti meistriškumo, noras išbandyti savo jègas; vaikinai labiau nei merginos jaudinasi dèl komandos pralaimèjimo. Žaisti krepšini merginas labiau $(p<0,05)$ nei vaikinus skatina galimybe gerai praleisti laika, ìdomiai pabendrauti, jos labiau nei vaikinai išgyvena dèl asmeniškai nepasisekusio žaidimo. Ištyrus krepšini žaidžiančiu studentu ir studenčiu išorinę sportinès veiklos motyvacija atskleista, kad vaikinams statistiškai patikimai būdingesni $(p<0,05)$ nei merginoms šie motyvai: visuomenès pripažinimas ir sportinè karjera. Finansinès paskatos, prizai, trenerio pagyrimai ir geri santykiai su treneriu svarbūs tiek merginoms, tiek vaikinams.

Raktažodžiai: sportinès veiklos motyvacija, vidine motyvacija, išorinè motyvacija, krepšinis.

\section{IVADAS}

K repšinis daugelyje pasaulio šalių yra prioritetinè sporto šaka. Ivairiuose straipsniuose bandoma teigti, kad krepšinis — tai vyriškas sportas, tačiau paskutiniais dešimtmečiais pastebèta, kad moterys ne mažiau nei stipriosios lyties atstovai yra pasirengę siekti pergalių. Todèl darosi svarbu žinoti, kokius motyvus ir kada reikia skatinti, kad krepšini žaidžiantys studentai ir studentès sèkmingai siektu norimu sportiniu rezultatų. Vis dažniau mokslininkai kelia klausimus: kokia nūdienos sportinès veiklos motyvacijos struktūra, esant naujoms socialinèms ir ekonominėms sąlygoms; kaip skatinti krepšini žaidžiančiu studentų ir studenčių motyvaciją? Sportinès veiklos motyvacija ịvairiose teorijose apibūdinama iš skirtingu perspektyvu (Rychman, Hamel, 1995; Flood, Hellstedt, 2002; Malinauskas, 2003 b; Malinauskas, 2006). Per pastaruosius dešimtmečius isitvirtino dvi teorijos, kuriomis aiškinama jaunuoliu sportinès veiklos motyvacija — sèkmès (laimejjimų) tikslų ir apsisprendimo (kognityvinio vertinimo) teorijos. 
Sėkmès tikslų teorijoje teigiama, kad asmens motyvacija priklauso nuo to, kokio tikslo jis siekia. Siekiami tikslai skirstomi i dvi kategorijas. Pirma kategorija - tai tikslai, susiję su geru užduoties atlikimu, tai asmens orientacija ị užduoti, kai individas pasirenka igūdžių tobulinimo ir kompetencijos augimo tikslus, čia asmeninio meistriškumo lygis vertinamas, lyginant su tuo, ką žmogus mokejo ir galejjo anksčiau — taip vertinamas ir užduoties sunkumo laipsnis. Antra kategorija - tai tikslai, susiję su laimejjimu prieš kitus, rungtyniavimu su kitais, tai orientacija ị save (i ego), kai asmuo užsibrěžia tikslus įrodyti savo kompetenciją, palyginti savo lygi su kitų asmenų (Duda et al., 1992; Duda, Hall, 2001).

Apsisprendimo teorijoje asmens motyvacija aiškinama pagal šaltini, iš kur elgesys yra valdomas, reguliuojamas, kas ji lemia (Deci, Ryan, 2000). Kadangi yra du šaltiniai (vidinis ir išorinis), tai galima skirti ir dvi motyvacijos rūšis - vidinę ir išorinę. Vidinè motyvacija - tai noras būti veiksmingam ir veikti dèl pačios veiklos. Tuomet sportininkas yra skatinamas vidinio pasididžiavimo, kuris ir yra tas užvedantis variklis, suteikiantis sportininkui nora siekti geriausio rezultato net ir tuomet, kai niekas to nevertina ar net nemato (Malinauskas, 2003 a). Išorinè motyvacija - tai išorinio atlygio siekis arba noras išvengti bausmès. Šią motyvacijos atmainą, priešingai nei vidinę, lemia išoriniai veiksniai - kitų žmonių neigiamas ar teigiamas požiūris, palaikymas. Pastarasis gali būti materialus (pvz., piniginès premijos, daiktinès dovanos) arba nematerialus, t. y. idealaus, neapčiuopiamo pobūdžio (pvz., pagyrimas, visuomeninis pripažinimas ar pareigu paaukštinimas). Siekti šių atpildų yra pagrindinis išoriškai motyvuoto sportininko tikslas (Malinauskas, 2003 a, 2003 b). Pasak teorijos pradininku (Ryan, Deci, 2000), tik tokioje veikloje, kurioje gali būti patenkinami asmens kompetencijos, autonomijos ir sąveikos poreikiai, galima tikètis stipresnès sportinès veiklos motyvacijos. Šių teoriju kūrejjai sutaria, kad abi teorijos pasisako už strategijas, kurios skatina orientaciją $\mathfrak{i}$ užduotí, o tai jau puoselejja vidinę motyvaciją.

Mokslininkams labiausiai rūpi, kaip skatinti vidinę motyvaciją, nes tik ji labiausiai veikia sportinius laimejjimus (Kardelis, Stakyte, 2003; Grajauskas, 2008). Kadangi mokslo studijų, kuriu metu būtų nagrinejjama, kaip vidinè ir išorinè motyvacija priklauso nuo lyties, vis dar stokojama, todèl būtini tokio pobūdžio tyrimai.

Galima aptikti tyrimų, kurių metu būtų analizuojami sportuojančių suaugusių asmenų motyva- cijos skirtumai pagal lyti. Ši mokslinė problema išsamiai tyrinèta N. Stambulovos (Stambulova, 1993, 1997; Стамбулова, 1999). Kai kurie lyčių skirtumai nustatyti jau pirmais sportinès karjeros etapais tiriant, kas motyvuoja vyrus ir moteris varžybų metu (Stambulova, 1993, 1997). Konstatuojama, kad sportuojančios moterys dažniau linkę išvengti nesėkmès (užuot siekę sẻkmès) nei sportuojantys vyrai. Vyrai dažniau motyvuoti siekti sèkmès, pergalių, meistriškumo viršūnių (Стамбулова, 1999). Nurodoma, kad vyrai labiau orientuojasi i laimèjimus nei moterys. Vyrams nei moterims yra svarbesni šie motyvai: mègdžioti garsius sportininkus, kuo labiau išgarsėti. Motyvai (būti pripažintiems varžovų, specialistų, teisèju) jiems svarbesni nei moterims. Vyrai visą gyvenimą linkę siekti sėkmès, o moterims, net ir baigusioms sportinę karjera, šis motyvas nebūdingas (Stambulova, 1993, 1997). Tyrimai parode, kad geri santykiai su treneriu daug svarbesni moterims, jas labiau motyvuoja emocinè trenerio parama (Стамбулова, 1999). Sportuojantiems vyrams svarbesni tobulinimosi motyvai, susiję su sportine veikla, su fiziniu tobulèjimu, charakterio ugdymu ir savo išvaizdos gerinimu. Sportuojančiu moteru stipresni šie motyvai: derinti sporta ir studijas, sportą ir darbą, sportą ir kitus pomėgius (Стамбулова, 1999). Ši sportuojančių suaugusiuju motyvacijos ypatumų analizè rodo tam tikrus lyčiu dimorfizmo dèsningumus: sportuojantiems vyrams būdingiausi šie motyvai — rungtyniauti ir siekti sèmès, o sportuojančioms moterims jie būdingi statistiškai patikimai mažiau (Fisher, 2001). Atsižvelgę i tai ir kèlėme hipotezę: krepšinį žaidžiančių studentų (merginų ir vaikinų) motyvacijos ypatumai priklauso nuo lyties: vaikinų motyvacija žaisti krepšini stipresnè.

Kadangi mūsų šalyje krepšiniui skiriamas didžiausias demesys, todèl šiuo tyrimu ir gilinamasi i krepšini žaidžiančiu studentų ir studenčių sportinès veiklos motyvacijos ypatumus, o tyrimo pagrindą sudaro probleminis klausimas: kokie sportinès veiklos motyvai būdingi abiejų lyčiu atstovams, o kokie būdingesni merginoms ar vaikinams. Taip pat svarbu nustatyti, kokie vidiniai ir išoriniai motyvai skatina jaunuolius issitraukti i šią veiklą.

Problemos aktualumą grindžiame tuo, kad empirinio pobūdžio mokslo darbų, nagrinejjančių didelio meistriškumo krepšininkų motyvaciją, yra nemažai Lietuvos ir užsienio literatūroje, tačiau tyrinejjančių skirtumus tarp krepšini žaidžiančių studenčių ir studentų pastaruoju metu yra nedaug. 
Tyrimo problema: kokie krepšini žaidžiančiu studentų (merginų ir vaikinų) sportinès veiklos motyvacijos ypatumai?

Tikslas — atskleisti krepšini žaidžiančių studentų (merginų ir vaikinų) sportinès veiklos motyvacijos ypatumus.

\section{Tyrimo uždaviniai:}

1. Ivertinti krepšini žaidžiančių studentų ir studenčių vidinę sportinès veiklos motyvaciją.

2. Ištirti krepšini žaidžiančių studentų ir studenčių išorinę sportinès veiklos motyvaciją.

\section{TYRIMO METODIKA IR ORGANIZAVIMAS}

Tyrimo metu taikyti šie metodai: apklausa (modifikuotas R. Malinausko (1998) klausimynas sportinès veiklos motyvacijai tirti) ir matematinè statistika (procentinis Studento $t$ kriterijus).

Tiriamiesiems buvo pateiktas dešimties motyvų sąrašas vidinei motyvacijai vertinti ir šešiu motyvų sąrašas išorinei motyvacijai tirti. Vidinę motyvaciją iprasmino šie motyvai: įdomi ir maloni veikla; galimybé gerai praleisti laiką; vidinio pasididžiavimo jausmas; noras patirti sėkmę; noras siekti meistriškumo; noras patirti sẻkmę; idomus bendravimas; noras išbandyti savo jègas; noras jaustis laimingam, išgyvenimai dèl asmeniškai nepasisekusio žaidimo, išgyvenimai dèl komandos pralaimèjimo. Išorinei motyvacijai tirti buvo pateiktas šių motyvų sąrašas: trenerio pagyrimai; visuomenès pripažinimas; prizai; finansinès paskatos; geri santykiai su treneriu; sportinè karjera. Tiriamieji turejo nurodyti visus tuos motyvus, kurie skatina juos žaisti krepšinį. Analizuojant pasirinktus motyvus, buvo apskaičiuojamas procentinis dažnis. Skirtumo patikimumas tarp tiriamuju vertintas pasitelkus procentini Studento $t$ kriteriju.

Tiriamaji kontingentą sudare 95 krepšini žaidžiantys studentai (41 mergina ir 54 vaikinai), kurių amžius - nuo 18 iki 24 metú. Tyrimui studentai atrinkti tikimybinès (dvipakopès mechaninès) atrankos būdu, atsitiktinai atrinktos aukštosios mokyklos ir atliktas ištisinis komandu, kuriose žaidžia studentai ir studentès, tyrimas. Buvo tiriami Lietuvos kūno kultūros akademijos (LKKA), Kauno medicinos universiteto (KMU) ir Vytauto Didžiojo universiteto (VDU) krepšinį žaidžiantys studentai - vaikinai ir merginos.

\section{REZULTATAI}

Ištyrus ir palyginus krepšini žaidžiančių studentų (merginų ir vaikinu) sportinès veiklos vidinę motyvaciją paaiškejo, kad tiek merginoms, tiek vaikinams krepšinis yra įdomi ir maloni veikla (1 lent.). Krepšinį žaidžiančių studenčiu ir studentų vertinimai išsiskyrè apibūdinant krepšini kaip galimybę gerai praleisti laiką $(\mathrm{p}<0,05)$ : merginoms šis motyvas yra svarbesnis nei vaikinams. Merginoms taip pat svarbesnis yra bendra-

\begin{tabular}{|c|c|c|c|c|}
\hline \multirow{11}{*}{$\begin{array}{l}1 \text { lentelè. Krep- } \\
\text { šini žaidžiančių } \\
\text { studentų (mer- } \\
\text { ginų ir vaikinų), } \\
\text { nurodžiusių vi- } \\
\text { dinius sportinès } \\
\text { veiklos motyvus, } \\
\text { procentiniai daž- } \\
\text { niai }\end{array}$} & Motyvai & $\begin{array}{c}\text { Merginos } \\
(\mathrm{n}=41)\end{array}$ & $\begin{array}{l}\text { Vaikinai } \\
(n=54)\end{array}$ & $\begin{array}{c}\text { Studento } t \text { kriterijaus reikšmė } \\
\text { ir patikimumo lygmuo }\end{array}$ \\
\hline & Idomi ir maloni pati veikla & 71 & 69 & $\begin{array}{c}0,21 \\
\mathrm{p}>0,05\end{array}$ \\
\hline & Galimybė gerai praleisti laiką & 90 & 74 & $\begin{array}{c}2,11 \\
\mathrm{p}<0,05\end{array}$ \\
\hline & Vidinio pasididžiavimo jausmas & 54 & 76 & $\begin{array}{c}-2,26 \\
p<0,05\end{array}$ \\
\hline & Noras patirti sèkmę & 63 & 85 & $\begin{array}{c}-2,45 \\
\mathrm{p}<0,05\end{array}$ \\
\hline & Noras siekti meistriškumo & 73 & 89 & $\begin{array}{c}-1,97 \\
\mathrm{p}<0,05\end{array}$ \\
\hline & Idomus bendravimas & 93 & 76 & $\begin{array}{c}2,41 \\
p<0,05\end{array}$ \\
\hline & Noras išbandyti savo jègas & 80 & 94 & $\begin{array}{c}-1,99 \\
p<0,05\end{array}$ \\
\hline & Noras jaustis laimingam & 78 & 80 & $\begin{array}{c}0,24 \\
p>0,05\end{array}$ \\
\hline & Išgyvenimai dẻl asmeniškai nepasisekusio žaidimo & 88 & 72 & $\begin{array}{c}2,01 \\
\mathrm{p}<0,05\end{array}$ \\
\hline & Išgyvenimai dẻl komandos pralaimèjimo & 68 & 87 & $\begin{array}{c}-2,21 \\
\mathrm{p}<0,05\end{array}$ \\
\hline
\end{tabular}




\begin{tabular}{|c|c|c|c|c|}
\hline Motyvai & $\begin{array}{c}\text { Merginos } \\
(\mathrm{n}=\mathbf{4 1})\end{array}$ & $\begin{array}{l}\text { Vaikinai } \\
(\mathrm{n}=54)\end{array}$ & $\begin{array}{c}\text { Studento } t \text { kriterijaus reikšmė } \\
\text { ir patikimumo lygmuo }\end{array}$ & \multirow{7}{*}{$\begin{array}{l}2 \text { lentelè. Krepšin } \\
\text { žaidžiančių studentų } \\
\text { (merginų ir vaikinų), } \\
\text { nurodžiusių išorinius } \\
\text { sportinès veiklos mo- } \\
\text { tyvus, procentiniai } \\
\text { dažniai }\end{array}$} \\
\hline Trenerio pagyrimai & 71 & 61 & $\begin{array}{c}1,03 \\
p>0,05\end{array}$ & \\
\hline Visuomenès pripažinimas & 76 & 94 & $\begin{array}{c}-2,43 \\
\mathrm{p}<0,05\end{array}$ & \\
\hline Prizai & 88 & 83 & $\begin{array}{c}0,69 \\
p>0,05\end{array}$ & \\
\hline Finansinès paskatos & 93 & 96 & $\begin{array}{c}-0,63 \\
p>0,05\end{array}$ & \\
\hline Geri santykiai su treneriu & 88 & 78 & $\begin{array}{c}1,32 \\
p>0,05\end{array}$ & \\
\hline Sportinès karjera & 78 & 94 & $\begin{array}{c}-2,21 \\
\mathrm{p}<0,05\end{array}$ & \\
\hline
\end{tabular}

vimo motyvas nei vaikinams $(\mathrm{p}<0,05)$. Vaikinai, žaisdami krepšini, labiau jaučia vidini pasididžiavimą nei merginos, ir tai leidžia manyti esant stipresnę jų vidinę motyvaciją. Apie stipresnę vidinę krepšini žaidžiančiu vaikinų motyvaciją taip pat byloja jų noras patirti sékmę, kuris jiems būdingesnis nei merginoms $(p<0,05)$. Krepšini žaidžiantys studentai labiau siekia meistriškumo, labiau nori išbandyti savo jègas nei krepšini žaidžiančios studentès. Pagal norą jaustis laimingam krepšini žaidžiantys vaikinai ir merginos patikimai nesiskyrė $(p>0,05)$. Merginas labiau nei vaikinus jaudina jų pačių blogas žaidimas, o ne komandos pralaimejjimas. Vaikinai labiau nei merginos jaudinasi dèl komandos pralaimejjimo $(\mathrm{p}<0,05)$. Jie džiaugiasi, kai laimi, bet labiau išgyvena pralaimèję.

Apskaičiavus krepšinį žaidžiančių studentu (merginų ir vaikinų), nurodžiusių išorinius sportinès veiklos motyvus, procentinius dažnius nustatyta, kad tiek merginoms, tiek vaikinams svarbūs trenerio pagyrimai (2 lent.) ir geri santykiai su juo. Krepšini žaidžiantys studentai (merginos ir vaikinai) statistiškai patikimai nesiskyrè pagal finansinių paskatu motyvą ir nora pelnyti prizus. Vadinasi, tiek krepšini žaidžiantys vaikinai, tiek merginos orientuotos ị galutinị tikslą (ị rezultatą), kai stengiamasi palyginti save su kitais ir juos nugalèti.

Tyrimo rezultatai, be to, parodè, kad krepšini žaidžiantiems vaikinams būdingesni $(p<0,05)$ nei merginoms šie motyvai: visuomenès pripažinimas ir sportinè karjera. Todèl galima teigti, kad krepšini žaidžiantys vaikinai labiau renkasi tikslą, orientuotą $\mathfrak{i}$ užduotị (tikslas orientuotas $\mathfrak{i}$ meistriškumą), ir jie didesni demesį kreipia į savo sportinès veiklos pagerinima, siekdami sportinès karjeros aukštumų.

\section{REZULTATŲ APTARIMAS}

Tyrimo hipotezė, kad krepšinį žaidžiančių studentų (merginų ir vaikinų) motyvacijos ypatumai priklauso nuo lyties (vaikinų motyvacija sportuoti yra stipresnè), pasitvirtino. Rezultatai parode, kad vaikinams būdinga stipresnè ir vidinè, ir išorinè sportinès veiklos motyvacija.

Pastaruju metu sportinès veiklos motyvacijos tyrimai (Ferrer-Caja, Weiss, 2000) atskleide, kad sparčiai auganti ekonomika, finansinis nestabilumas, platūs ryšiai su daugelio pasaulio šalimis keičia jaunu žmoniu sportinės veiklos motyvacijos struktūrą. Didejjanti visuomenès konkurencija, finansiniai veiksniai veikia ir sporto sriti. Tai patvirtino ir atlikto tyrimo rezultatai: finansinès paskatos yra svarbios beveik visiems vaikinams ir merginoms (96 ir 93\%).

Sportinès veiklos motyvacijos tyrèjai (Mathes, Battista, 1985; Flood, Hellstedd, 2002), analizavę motyvacijos skirtumus tarp vyrų ir moterų, nustate, kad sportininkų vyrų ir moterų motyvacija yra susijusi su lyties prigimtimi, kurią socialiniai-ekonominiai veiksniai paveikia tik iš dalies. Be abejo, neturetų būti ignoruojamos ir kitos teorijos (lyties socializacijos ir feministinès), tinkančios lyčiu skirtumams pagal motyvaciją paaiškinti. Krepšini žaidžiančioms moterims svarbesnis bendravimas, malonumas negu geri sportiniai rezultatai (Newton et al., 2000; Laparidis et al., 2003). Šiuos teiginius patvirtino ir atliktas tyrimas: krepšinis merginoms - tai galimybè gerai praleisti laiką, įdomiai pabendrauti. Krepšini žaidžiančios studentès labiau išgyvena dèl asmeniškai nepasisekusio žaidimo, o ne dèl komandos pralaiméjimo. Taip atsitinka dèl to, kad merginos jaučia spaudimą, susijusi su aktyvesniu sportavimu. Energija, kurią tenka parodyti žaidimo metu, gali būti traktuojama kaip nemoteriška, nes fizinè veikla skatina raumenu 
augimą. Dèl to, net jei merginos ir renkasi sportinę veiklą, jų šios veiklos motyvai skiriasi nuo vaikinu (Laparidis et al., 2003).

Sportininku vyru polinkis demonstruoti varžymąsi, o sportininkių moterų - socialinius motyvus, buvo jau įrodytas (Malinauskas, 2006). Šis tyrimas taip pat parodè, kad vaikinams komandos pergalès siekis yra svarbesnis negu asmeninè sėkmė. Krepšini žaidžiančių studentų motyvacijos struktūroje vyrauja žinojimo ir tobulumo siekiai, o studenčių - emocijų ir malonumo potyris. Abieju lyčių sportininkams yra svarbūs saugumo motyvai - finansinès paskatos ir geri santykiai su treneriu. Tai atitinka ir kitų tyrèjų (Newton et al., 2000) išvadas.

Būtina pabrèžti, kad lyčių skirtumai nustatyti ne tik pagal sportinès veiklos motyvus, bet ir pagal akademinès veiklos motyvaciją (Karanauskienè, Kardelis, 2005). Lyčių skirtumai pagal akademinès veiklos ir pagal sportavimo motyvacijas atskleisti tiriant LKKA studentus (Kardelis, Karanauskienė, 2003). Tai gali būti paaiškinta remiantis tiek lyties socializacijos teorijomis, teigiančiomis, kad vaikai iš savo tėvų, mokytojų ir kitų jiems reikšmingų asmenų perima lyčių vaidmenų suvokimą bei tam tikrus socialinius požiūrius (Reynolds, 2003), tiek lyties feministinemis teorijomis (Roth, Basov, 2004), teigiančiomis, kad skirtumai tarp lyčių — ne natūralus faktas, o sudètinis socialinių, istorinių ir kultūrinių reiškinių produktas, kad lytis bei lyčių skirtumai lemia gyvenimo turini, pagrindinius so- cialiai priimtinus motyvus, veikimo būdus bei vyrų ir moterų požiūrị i socialini pasaulį.

Kadangi gero mikroklimato ir ì užduotị orientuotos aplinkos kūrimas yra vienas iš svarbiausių šiuolaikinès edukacinès paradigmos uždavinių, tai studentų ir studenčių motyvavimo žaisti krepšini priemonių paieška galètų būti tolesnių tyrimų objektas.

\section{IŠVADOS}

1. Ivertinus krepšinị žaidžiančių studentų ir studenčių vidinès sportinès veiklos motyvacijos ypatumus paaiškèjo, kad vaikinams būdingesni $(\mathrm{p}<0,05)$ nei merginoms šie motyvai: vidinio pasididžiavimo jausmas, noras patirti sėkmę, noras siekti meistriškumo, noras išbandyti savo jègas, vaikinai labiau nei merginos jaudinasi dèl komandos pralaimèjimo. Žaisti krepšini merginas labiau $(\mathrm{p}<0,05)$ nei vaikinus skatina galimybè gerai praleisti laika, idomiai pabendrauti, jos labiau nei vaikinai išgyvena dèl asmeniškai nepasisekusio žaidimo.

2. Ištyrus krepšini žaidžiančių studentų ir studenčių išorinę sportinės veiklos motyvaciją atskleista, kad vaikinams statistiškai patikimai nei merginoms būdingesni $(p<0,05)$ šie motyvai: visuomenès pripažinimas ir sportinè karjera. Finansinès paskatos, prizai, trenerio pagyrimai, o geri santykiai su treneriu svarbūs tiek merginoms, tiek vaikinams.

\section{LITERATŪRA}

Deci, E. L., Ryan, R. M. (1985). Intrinsic Motivation and Self-determination in Human Behavior. New York: Plenum Press.

Deci, E. L., Ryan, R. M. (2000). The "what" and "why" of goal pursuits: Human needs and the self-determination of behavior. Psychological Inquiry, 11, 227-268.

Duda, J. L., Fox, K. R., Biddle, S. J., Armnstrong, N. (1992). Children's achievement goals and beliefs about success in sport. British Journal of Educational Psychology, 62, 313-323.

Duda, J. L., Hall, H. K. (2001). Achievment goal theory in sport: Recent extensions and future directions. In R. Singer, H. Hausenblas, C. Janelle (Eds.), Handbook of research in sport psychology (pp. 417-434). New York: John Wiley \& Sons.

Ferrer-Caja, E., Weiss, M. R. (2000). Predictors of intrinsic motivation among adolescent students in physical education. Research Quarterly for Exercise and Sport, 71, 267-279.

Fisher, L. A. (2001). Career transitions in sport: International perspectives. The Sport Psychologist, 15 (4), 450-452.

Flood, S., Hellstedt, J. (2002). Gender differences in motivation for intercollegiate athletic participation. Journal of Sport Behaviour, 14, 159-168.
Grajauskas, L. (2008). Jaunuju (12-14 metu) orientacininku rengimo modeliavimas taikant treniravimo priemoniu ir metodu ivairovę: daktaro disertacija. Šiauliai: ŠU.

Karanauskienè, D., Kardelis, K. (2005). The relationship between student's academic identity and academic achievements. Socialiniai mokslai, 1 (47), 62-70.

Kardelis, K., Karanauskienė, D. (2003). Studentų suvokto aukštosios mokyklos identiteto bei įvaizdžio ir jų veiklos motyvacijos sąsaja. Ugdymas. Küno kultūra. Sportas, 4 (49), 25-30.

Kardelis, K., Stakytè, S. (2003). Skirtingo fizinio aktyvumo paaugliu mokymosi motyvacijos ir psichosocialinès sveikatos duomenu sąsaja. Sporto mokslas, 4 (34), 39-43.

Laparidis, K., Papaioannou, A., Vretakou, V., Morou, A. (2003). Motivational climate, beliefs about the bases of success, and sportsmanship behaviors of professional basketball athletes. Perceptual and Motor Skills, 3, 1141-1151.

Malinauskas, R. (2003 a). Didelio meistriškumo dvikovos sporto šaku sportininkų ir jų rezervo motyvacijos ypatumai. Sporto mokslas, 1 (31), 19-23.

Malinauskas, R. (2003 b). Sportinès veiklos svarbiausios vertybès ir motyvacijos formavimo ypatumai. Olimpinis švietimas ir kultūra: mokslinès konferencijos medžiaga (pp. 61-63). Vilnius: LOA. 
Malinauskas, R. (2006). Sporto pedagogu ir sportininku socialinio psichologinio rengimo ypatumai: monografija. Vilnius: LSIC.

Malinauskas, R. (1998). Vaikinų, kurie renkasi boksą, motyvacijos ypatumai. Sporto mokslas, 3 (12), 20-23.

Mathes, S. A., Battista, R. (1985). College men and women's motives for participating in physical activity. Perceptual and Motor Skills, 16, 719-726.

Newton, M., Duda, J. L., Yin, Z. (2000). Examination of the psychometric properties of the perceived motivational climate in Sport Questionnaire-2 in a sample of female athletes. Journal of Sport Sciences, 18, 275-290.

Reynolds, F. (2003). Initial experiences of interprofessional problem-based learning: A comparison of male and female students' views. Journal of Interprofessional Care, 17 (1), $35-44$.

Roth, A., Basov, S. (2004). Femininity, Sports, and Feminism. Journal of Sport \& Social Issues, 28 (3), 245-265.
Ryan, R. M., Deci, E. L. (2000). Self-determination theory and the facilitation of intrinsic motivation, social development, and well-being, American Psychologist, 55, 68-78.

Rychman, M., Hamel, J. (1995). Male and female adolescents motives related to involvement in organized team sports. International Journal of Sport Psychology, 26, 383-398.

Stambulova, N. (1997). Sports career psychological models and its applications. In R. Lidor, M. Bar-Eli (Eds.), Proceedings of the IX World Congress of Sport Psychology (pp. 655-657). Israel: Wingate institute.

Stambulova, N. (1993). Two ways of sports career psychological descriptions. In S. Serpa, J. Alves, V. Ferreira, A. P. Brito (Eds.), Actas do VIII Congresso Mundial de Psicologia do Desporto (pp. 762-764). Lisboa: Lisboa university.

Стамбулова, Н. Б. (1999). Психология спортивной каpьеры. Санкт-Петербург: Центр карьеры.

\title{
THE PECULIARITIES OF MOTIVATION FOR SPORTS ACTIVITY AMONG STUDENTS PLAYING BASKETBALL
}

\author{
Romualdas Malinauskas \\ Lithuanian Academy of Physical Education, Kaunas, Lithuania
}

\begin{abstract}
The factors of motivation for sports activity of students are researched insufficiently. Various motivation peculiarities are constantly presented in modern sport studies. Male and female students playing basketball seeking for good results in sports activity have their own motivation and goal setting strategies (Flood, Hellstedt, 2002). Only having clear goals and strong motivation it is possible to achieve victory (Malinauskas, 2006). Very often athletes face failures because they set goals and demonstrate such peculiarities of motivation that do not satisfy their possibilities or are not concrete. The problem of the research was that we still lack that data, that would reveal the level of motivation of male and female students playing basketball. Research question was as follows: what are the peculiarities of motivation for sports activity of male and female students playing basketball?

The object of the research was the peculiarities of motivation for sports activity among male and female students playing basketball. It was presumed that male basketball players demonstrate a higher level of motivation for sports activity than female basketball players. The purpose of this investigation was to disclose the peculiarities of motivation for sports activity among male and female students playing basketball. The study raised the following tasks: to study and compare male and female students playing basketball according to the intrinsic motivation for sports activity; to reveal and compare the extrinsic motivation for sports activity of female and male students.

The survey of students playing basketball employed R. Malinauskas method for identifying intrinsic and extrinsic motivation. The hypotheses of mathematical statistics were tested by the t-test. For the investigation, based on a survey questionnaire, a random sample was composed of 95 students playing basketball (41 girls and 54 boys aged 18 to 24 years at the Lithuanian Academy of Physical Education (LAPE), Kaunas Medical University (KMA) and Vytautas Magnus University (VMU).

Having compared the investigation results of motivation for sports activity among male and female students playing basketball it was established that intrinsic and extrinsic motivation of male students playing basketball was in many aspects stronger than the motivation of female students playing basketball. It was proved that male students playing basketball indicated $(\mathrm{p}<0.05)$ the following most important intrinsic motives: to strive to win, to try one's best, to seek for mastership. It was determined that male and female students playing basketball differed statistically significantly $(\mathrm{p}<0.05)$ according to their extrinsic motivation: male students playing basketball had stronger motives for career development and recognition from the public.
\end{abstract}

Keywords: motivation for sports activity, intrinsic motivation, extrinsic motivation, basketball.

Gauta 2008 m. rugsèjo 30 d.

Received on September 30, 2008

Priimta 2008 m. gruodžio 9 d.

Accepted on December 9, 2008
Romualdas Malinauskas

Lietuvos kūno kultūros akademija

(Lithuanian Academy of Physical Education)

Sporto g. 6, LT-44221 Kaunas

Lietuva (Lithuania)

Tel +370 37209050

E-mail r.malinauskas@1kka.lt 